\title{
Феномен милосердя в дихотомії «Захід-Схід»
}

\author{
Ходанич Ю. М., Ужгородський національний університет
}

Стаття присвячена аналізу феномену милосердя крізь призму західної та східної ціннісних установок (типів світоглядів). Милосердя, базуючись на принципах гуманності, а також маючи світський та релігійний виміри, пронизує своїм змістом як західне, так і східне світобачення та розуміння місця людини в суспільстві. Традиціоналізм східної парадигми мислення та їі орієнтованість на «буття», а, відповідно, прогресизм західної парадигми мислення та іiї орієнтованість на «володіння» зумовлюють різний підхід до феномену милосердя. Милосердя на Заході сприймається крізь призму любові до людини, на Сході - любові до всього живого (людина сприймається як частинка цілого). Феномен милосердя проаналізований в контексті релігійно-філософських (конфуціанство, даосизм) та релігійних (християнство, іслам, буддизм) традицій. Особлива увага звернена до розуміння милосердя крізь призму християнської та ісламської антропології. Також надано характеристику принципу ахімси, що є суміжним із милосердям у східній традиції світобачення.

Ключові слова: цінність; милосердя; культура; ахімса; антропологія; християнство; іслам

\section{Phenomenon of Mercy in the Dichotomy «West-East»}

\section{Khodanych Yu. M., Uzhgorod National University}

The aim of the article is to analyze the phenomenon of mercy through the prism of value-ideological background of the western and eastern types of culture and thinking. The main methods of research include: socio-cultural analysis, axiological and critical analyses.

The article is devoted to the analysis of the phenomenon of mercy through the prism of Western and Eastern values (types of worldviews). Mercy, based on the principles of humanity, as well as having secular and religious dimensions, permeates by its content both Western and Eastern worldviews and understanding of the person's place in society. The article proves the opinion as to the Western orientation to «possession», while the East is oriented to «being», which essentially determine the understanding of mercy. The phenomenon of mercy is analyzed by the author in the context of religious and philosophical (Confucianism, Taoism), religious (Christianity, Islam, Buddhism) and secular positions. The study shows the perception of mercy in various oriental traditions, as well as its differences. Special attention is paid to the understanding of mercy through the prism of Christian and Islamic anthropology. It also describes the principle of ahimsa, which is adjacent to mercy in the Eastern tradition of the worldview.

The author comes to the conclusion that the sociocultural factor of the conditional comprehension of mercy proves to be decisive in the context of the «West-East» dichotomy, moreover, it forms different approaches to its understanding. Pragmatically oriented Western culture is based on the philosophical and scientific outlook and Christianity. Mercy here is understood not as a moral imperative, but as a person's choice, the manifestation of his/her attitude to others. A person appears to be an individual who acts through his/her freedom of will, the priority of a person over the social and the state comes to the fore. The object of mercy is a person, while nature is perceived as the object of possession and consumption for human needs. The social practice of mercy is embodied in the activities of charitable, volunteer and other humanitarian organizations and is based on a combination of individual and social benefit. In its turn, the Eastern paradigm of thinking is based on religious norms, morality, is more spiritually oriented, perceives the phenomenon of mercy as an inalienable attribute of human existence, and the person himself/herself as a particle of the whole (nature, space, etc.), primarily as a member of the community. Hence the object of mercy appears not only a person but all living beings, whose harmony cannot be violated.

Keywords: value; mercy; culture; ahimsa; anthropology; Christianity; Islam

\section{Феномен милосердия в дихотомии «Запад-Восток»}

\section{Ходаныч Ю. М., Ужгородский национальный университет}

Статья посвящена анализу феномена милосердия сквозь призму западной и восточной ценностных установок (типов мировоззрений). Милосердие, основываясь на принципах гуманности, а также имея светский и религиозный измерения, пронизывает своим содержанием как западное, так и восточное мировоззрение и понимание места человека в обществе. Традиционализм восточной парадигмы мышления и его ориентированность на «бытие», а, соответственно, прогрессизм западной парадигмы мышления и его ориентированность на «владение» об- 
условливают различный подход к феномену милосердия. Милосердие на Западе воспринимается сквозь призму любви к человеку, на Востоке - любви ко всему живому (человек воспринимается как частица целого). Феномен милосердия проанализирован в контексте религиозно-философских (конфуцианство, даосизм) и религиозных (христианство, ислам, буддизм) традиций. Особое внимание обращено к пониманию милосердия сквозь призму христианской и исламской антропологии. Также охарактеризован принцип ахимсы, что является смежным с милосердием, в восточной традиции мировоззрения.

Ключевые слова: ценность; милосердие; культура; ахимса; антропология; христианство; ислам

\section{Постановка проблеми.}

$\Pi$ роблема взаємодії західної та східної типів культури вже не одне століття турбує мислителів, що пов'язано, 3 одного боку, з відмінностями даних культур, 3 іншого - потребою в пошуку спільних точок для їх зближення. Особливої актуальності ця проблема набуває за сучасних глобалізаційних процесів, що характеризуються як посиленим діалогом та взаємодією різноманітних культур та світоглядних (ціннісних) установок, так і значною мірою їх уніфікацією. В свою чергу феномен милосердя, що походить із розуміння гуманності, в тій чи іншій мірі пронизує як західні, так і східні ціннісні орієнтації, а тому може бути важливим чинником на шляху до формування глобальної етики, що базується як на релігійних, так і світських установках. При цьому, перш за все, постає потреба в аналізі відмінностей у розумінні милосердя крізь призму дихотомії «Захід-Схід».

\section{Аналіз досліджень і публікацій.}

Питання діалогу та пошуку спільних контекстів Заходу та Сходу було предметом філософського осмислення М. Бердяєва, Б. Вишеславцева, Ф. Ніцше, Ж.-П. Сартра, В. Соловйова, Е. Фромма, А. Швейцера, А. Шопенгауера, К. Ясперса та інших мислителів. Сучасні дослідження ціннісних орієнтацій західної та східної парадигми мислення пов'язані з такими дослідниками як Д. С. Берестовська, Е. П. Борзова, П. А. Поломошнов, В. І. Самохвалова, В. С. Стьопін та іншими.

На дисертаційному рівні проблему ціннісних установок Заходу та Сходу дослідили В. В. Васильєв та Л. А. Швачкіна. Зокрема, В. В. Васильєв приходить до висновку, що базові цінності західноєвропейської культури були сформовані в епоху Просвітництва завдяки Т. Гоббсу, Дж. Локку, Ш.-Л. Монтеск'є, Ж. Ж. Руссо, І. Канту. В свою чергу визначити ціннісні орієнтації Сходу досить складно, адже східна культура представлена великою кількістю різних за своїм змістом учень та напрямів, які переважно грунтуються на релігії та моралі як суспільних феноменах. Якщо брати до уваги брахманістську традицію, то тут цінностями, на думку В. В. Васильєва, постають система варн та дхарма (божественно встановлений закон, що іманентно містить в собі цінність колективізму); в буддизмі - дхарма та індивідуальне пізнан- ня дхарми; в даосизмі - природа або божественне провидіння та рівність всіх перед природним законом; у конфуціанстві - сім'я та мораль; на Арабському Сході - релігія, мораль та щастя всіх, однак зміст якого визначається верховним правителем [3, c. 11-12].

В. В. Васильєв виділяє ієрархію цінностей Заходу та Сходу. Зокрема, західний світогляд представлений такими ціннісними установками, як закон і порядок (які переважно формуються активністю «знизу»); свобода (переважно індивідуальна); рівність та безпека; власність, розум і знання; мораль, сім'я, природа. В свою чергу східний світогляд представлений наступними цінностями: закон, установлений «зверху»; недіяння і підкореність; мораль і релігія [3, с. 15-16].

Метою дослідження є розкрити феномен милосердя, виходячи з горизонтів західного та східного світобачення.

\section{Виклад основного матеріалу.}

Диференційованість західної та східної парадигм мислення визначає їх диференційований підхід до феномену милосердя. Якщо в західному світогляді милосердя розглядається переважно в контексті філософського осмислення, християнської етики та суспільної практики, то на Сході основне його розуміння випливає з релігійних норм, моральних установок та крізь призму невід'ємного атрибуту людини як частини цілого (всесвіту, природи).

На думку Л. А. Швачкіної, для східного типу світогляду милосердя, допомога іншому як певні культурні практики важливі в тій мірі, в якій підтримують існуючу соціальну світобудову, їх об'єкт є частина цілого. В свою чергу в західному типі культури об'єкт допомоги та співстраждання стає суб' єктом. Даний тип демонструє, що людина може потребувати допомоги чи надавати іiї в силу притаманної ій свободи, незалежності та самостійності у виборі життєвого шляху [13, с. 17].

Якщо намагатися порівнювати ціннісні позиції Заходу та Сходу, то західна культура більш прагматична за своїм змістом, орієнтована на інтелектуальний потенціал, перетворення суспільства, розвиток індивідуальності. Вона базується на філософії та науці. В свою чергу східна культура базується на релігії, на уявленнях про мораль та духовність, спрямована на самовдосконалення 
людини як частинки чогось цілого (космосу, природи, суспільства). Заходу переважно характерний динамізм, прогрес, суспільні зміни, активна участь індивіда, а Сходу - переважно стабільність, незмінність суспільного устрою, пасивність індивіда щодо суспільних змін.

Як вказує В. І. Самохвалова, чеснота на Сході «розглядається як узгоджена поведінка 3 власною природою і тим самим із загальним порядком світу; і тому чеснота - поняття скоріше структурно-організаційне, аніж етичне». Навіть у конфуціанстві, що близьке західному менталітету, «чеснота стоїть нижче заслуги, оскільки остання визначається здатністю людини давати оцінку та обирати добро, коли вона може вчинити і добро, i зло. Християнство ж вище цінує чесноту,оскільки вона поєднана 3 цнотливістю душі, яка не думає про саму можливість зла» [8, с. 130].

В свою чергу Захід «все розуміє через людину та їі діяльність, яка так чи інакше змінює світ», а Схід стверджує, що «людина в своїй діяльності, перш за все, повинна слідувати порядку творчості самого світу (тобто в найширшому сенсі діяти «за прецедентом»...), космосу». Схід «більш уважний до форми, аніж до змісту, до ритуальності, аніж до спонтанності, до традиції, аніж до новаторства. I самі традиційні й ритуальні форми не стільки соціально обумовлені конвенції, скільки складно здійснена символізація розуміння самого світу та його власного порядку (в прояві та функціонуванні) через визначені формальні «фігури» і «позиції». Позиції ритуальної форми настільки непохитні, наскільки непохитний порядок самого світу в його об'єктивному бутті» [8, с. 137-138]. Отже, якщо «західна» людина спрямовує свою діяльність на перетворення світу, то «східна» слідує природному розвитку, вважаючи себе лише його частинкою, а не «володарем».

Сформована на основі наукової парадигми західна культура є техногенною, адже спрямована на перетворення світу. Східна традиціоналістська система цінностей передбачає людину включеною в організм природи, ніби розчиненою в ній; вектор людської активності спрямований не стільки назовні, скільки всередину, на самовиховання, самообмеження, включення в традицію [10, с. 12].

Ознака традиціоналізму та антитрадиціоналізму на Сході та Заході відповідно обумовлює суспільну практику реалізації милосердя. Адже, до прикладу, постійний пошук «нового» (нових форм) на Заході привів до формування благодійних, волонтерських організацій, а також понять спонсорство, меценатство, фандрейзинг тощо, що не притаманно для східної культури. Милосердя в рамках останньої не потребує певної інституціалізації, прагматичної раціональності, прогнозування тощо, натомість достатньо кооперації.
В західній культурі основою етики розуміється іiі раціональне обгрунтування, що бере свій початок ще з Сократа, який, перш ніж визначити як жити морально (за чеснотами), вважав за необхідність зрозуміти, чим є сама чеснота. На противагу Заходу, в східній культурній традиції «істина не відділювалась від моральності і моральне вдосконалення розумілось умовою та підставою для осягнення істини. Істина відкривається лише моральним людям». До прикладу, «один і той же ієрогліф «дао» означав у древньокитайській культурі закон, істину та моральний життєвий шлях». На противагу Сократу, коли учні Конфуція питали у нього, як розуміти «дао», він давав кожному різні відповіді, оскільки кожнен із його учнів пройшов різний шлях морального вдосконалення [10, с. 14].

Світогляд Сходу базується на постулаті, що людина не $є$ вільною, натомість визначеною космічним законом чи Богом. Передбачається орієнтація на колективізм та заперечення автономіі, свободи, гідності. На Сході лише через взаємовідносини 3 іншими можливо зрозуміти власне «Я». Східний тип мислення передбачає переважно орієнтованість на внутрішній світ людини, натомість західний тип звертає увагу на індивідуальність та унікальність особистості. Східний світогляд більше зорієнтований на осягнення внутрішньої духовності людини, а західний - на освоєння зовнішнього оточуючого світу та його активне перетворення [1, с. 132-133].

Якщо східна етика споглядальна, консервативна та аскетична, то західна - активна, ліберальна та утилітарна. Якщо східний тип мислення - традиціоналістський (звертання та утвердження традицій предків), то західний - навпаки, прагне до руйнування традиційності, соціальної творчості та прискорює темп життя [1, с. 134].

На Заході милосердна особистість сприймається крізь призму суб'єкта, є «діячем», що обрав на основі вільної волі певний шлях дії. Натомість на Сході милосердя не є певною заслугою, а сприймається як свого роду моральний імператив, що повинен бути частинкою буття людини та проявлятися як її ставлення до оточуючого іiї світу.

Н. В. Шелковая називає Захід «культурою розуму», а Схід - «культурою серця». Культура Сходу передбачає «входження у світ Іншого, проживання світу Іншого». Людина Сходу не намагається знати світ та Іншого, оскільки це неможливо й навіть абсурдно, натомість намагається відчути світ та Іншого [14, с. 145].

Східне мислення позаопозиційне (для Заходу характерні опозиції суб'єкт-об'єкт, внутрішній-зовнішній світ тощо), інтегративне. Воно виробило основний принцип існування та діяльності людини - споглядання, інтуїтивне одкровення та відмову від будь-яких форм насильства, що по- 
рушують баланс сил взаємодії та природний хід життя [11, с. 84].

Е. П. Тіхонова виділяє ряд смислових антиномій, що визначають розвиток культур Заходу та Сходу. Зокрема, щодо Сходу: гармонійне співіснування людини 3 природним середовищем проживання; любов до світу; інтуїтивне знання, містика; традиціоналізм, стабільність життя общини і держави; споглядання, медитація; дао. В свою чергу на Заході: держава (демократія, рівність, свобода); техніко-технологічне перетворення світу, підкорення природи; любов до людини; раціональне знання, культ науки; модернізація (індустріалізація, прогрес, інновація); активна фізична дія; логос $[11$, с. 84$]$.

«Червоною лінією» проходить відмінність у способі існування людини Заходу і Сходу: перша орієнтована на володіння, друга - на буття. Це певні смислові схеми, які формують тип свідомості, а, отже, тип особистості певної культури. Орієнтація на володіння західної культури передбачає чітке розрізнення людини як суб'єкта та природи як об'єкта. Західна людина прагне «перетворити весь світ в об'єкт володіння та обов'язкового практичного використання». Людина Заходу активно використовує природу для задоволення своїх потреб. Вона орієнтована на раціональне осягнення та використання світу. Сутністю екзистенційною установкою володіння є споживацтво - прагнення людини захопити весь світ [11, с. 85]. Саме тому явища індивідуалізму, споживацтва «походять» iз західної традиції, що базується на визнанні індивідуальності людини.

В свою чергу «буття» $є$ ціннісно-смисловою орієнтацією та парадигмою існування культури Сходу. Для неї характерні альтруїзм, життєлюбство та причетність до світу, реалізація людиною духовної свободи та творчості. Традиційне суспільство Сходу зорієнтоване на збереження вітальної сили та колективної пам'яті общини. Світ постає як єдність усіх форм та рівнів існування, а також є одухотвореним, де кожна річ має свій зміст. Це орієнтація на гармонійне співіснування людини та оточуючого їі світу. Буття як реалізація життєво активної сили людини й світу передбачає відмову від власного егоїзму та зорієнтованості на собі. Саме звідси важливий принцип ставлення людини до світу в східній культурі - недіяння (у-вей). Це життєвий принцип зовнішньо-фізично пасивного існування людини та споглядання суті речей, проте це водночас внутрішньо-психічна дія людина, спрямована на пізнання гармонії й сенсу існування світу $[11$, с. 86$]$.

Дихотомія «буття-володіння» яскравим чином показує відмінності щодо розуміння милосердя в західній та східній культурах. Так, на Заході, який зорієнтований на парадигму «володіння», мило- сердя переважно спрямовується лише на людину (людство), натомість на Сході, що будується на парадигмі «буття», милосердя поширюється на все живе (природу як таку). Слід тут додати, що західна культура мислення доволі чітко відділяє людину від природного середовища їі існування. Природа сприймається не як об'єкт для милосердного ставлення, а як об'єкт активного використання для потреб людини. Якщо милосердя на Заході сприймається крізь призму любові до людини, то на Сході - любові до всього живого, а не лише людини. Тут людина усвідомлює себе частинкою цілого, а милосердя стає проявом ставлення до цього цілого.

3 точки зору конфуціанства, милосердя тісно пов’язане з ритуалом («лі») та спрямоване на збереження й сакралізацію традиційного соціального устрою. Л. А. Швачкіна вказує з цього приводу, що милосердя чітко випливає 3 імперативу служіння суспільства та виконанням визначених обов'язків. Моральна поведінка є та, що заснована на принципі «золотої середини» як втілення ідеалу порядності й безкорисної любові до світу та людей $[13$, с. 23$]$. В свою чергу в даосизмі, на противагу конфуціанству, милосердя сприймається як те, що суперечить принципу Дао як утвердженню природної необхідності. Милосердя постає втіленням «деградації Дао» та свідчить про відсутність гармонії в суспільстві [13, с. 24].

Традиції даосизму та конфуціанства не сприймають розуміння «прав людини», прав громадянина, свободу особистості в їх західному розумінні, адже вони не відображають сутності гідності людини та того аксіологічного змісту, що вкладається в розуміння людини східними традиціями. Основу ж китайського суспільства, до прикладу, складали сім'я та рід [2, с. 302-303]. Таким чином, західна світоглядна традиція зорієнтована на індивідуальне в людині, а східна - на розуміння людини як члена спільноти, як частинки чогось цілого, що невіддільна від середовища існування (природи, космосу тощо).

Відмінностями характеризуються також ісламський та європейський цивілізаційні модулі. Зокрема, весь ісламський світ об'єднує людей, які при всіх відмінностях в культурі, традиціях, менталітеті тощо усвідомлюють свою належність до єдиної історико-духовної спільноти - всесвітньої умми. Окрема особистість тут малозначима, найважливішу роль відіграє саме релігія (іслам), що формує єдине ставлення до світу, суспільства та людини. Домінантною постає мораль в системі суспільних відносин, натомість особистісні інтереси вторинні. Саме належність до роду, клану визначає суспільний статус людини [2, с. 303]. В свою чергу християнство як західний тип релігії базується на визначенні кожної людини як окре- 
мої особистості, що перебуває у зв’язку з Богом, а через це вже з Церквою. При цьому індивідуальність людини передує, на відміну від ісламу, іiі суспільності або колективності.

Сутнісні характеристики християнської (західної релігійної течіï) та ісламської антропології також різняться. Інтерес християнства спрямовується на моральне самовдосконалення особистості в напрямку Бога та 3 допомогою Бога. Людина $\epsilon$ «богоподібною» - створена на образ і подобу Божу. Натомість, в ісламі всередині людини немає Бога, а тим самим немає внутрішньо природно закладеної гріховності. При цьому людина в ісламі зобов' язується до сповнення волі Аллаха на землі, підтримання встановленого Аллахом порядку та закону. Людина сприймається по відношенню до Аллаха в двох аспектах: як «раб Аллаха», проте не в значенні відсутності свободи чи поневолення, але в розумінні здійснення свідомого поклоніння Аллаху. Іншими словами, раб Аллаха $є$ той, хто здійснює його волю на землі. Другий аспект - людина визнається «намісником» Аллаха на землі, що означає, зокрема, можливість панувати над усім земним створінням. Намісництво передбачає «вірність Аллаху та перемогу над своєю моральною слабкістю» [6, с. 11-12].

Мораль християнства спрямована всередину, пов'язана з пізнанням духовності в самій людині, натомість мораль ісламу орієнтується назовні виконання людиною заданих Аллахом приписів та місії. Таким чином, якщо християнин, що від природи наділений свободою волі, повинен вирішувати протягом життя складні питання вибору «добро-зло», то мусульманин зобов'язаний лише слідувати встановленим наперед Аллахом приписам. Отже, ісламська мораль визначається «дотриманням чи ухиленням від зовнішньо встановлених Аллахом норм добра». Головною моральною цінністю в ісламі постає діяльність людини, що реалізує на практиці служіння Аллаху [7, с. 83-85].

Відносини між Аллахом та людиною в ісламі реалізовуються за схемою: від людини - покора та поклоніння, від Аллаха - керівництво та милосердя. Що стосується безпосередньо милосердя, то воно спрямоване лише щодо праведників, які покоряються волі Аллаха, та правомірних мусульман. Тих же, що впадають у гріх, чекають суворі покарання [6, с. 12-13].

На відміну від ісламу, в християнстві відносини між Богом та людиною будуються на основі любові як головної заповіді. При цьому любов до Бога і любов до людини ототожнюються. Милосердя Боже поширюється не лише на праведників, але й грішників та навіть тих, хто не вірить. Кожному дається можливість звернутися до Бога й покаятися.

Важлива відмінність між ісламом та христи- янством полягає в аспекті релігійного чи морального вдосконалення людини: в ісламі таке вдосконалення йде в напрямку від учинків до якостей душі, а в християнстві, навпаки, від якостей душі до вчинків. Таким чином, акцент в ісламі зосереджений на досконалості вчинків, а в християнстві - на досконалості душі [6, с. 15]. Іншими словами, якщо мотивація християн скерована до серця, то мусульман - до волі (вчинків).

Імператив добрих вчинків в ісламі підкріплений численними вказівками Корану на те, що добро вигідне людині, оскільки буде, безумовно, винагороджене без залишку. Більше того, добрі вчинки накопичуються до блага того, хто їх чинить, i в день воскресіння забезпечать людині відплату. Бог випробовує і спокушає людину на добро-зло, проте вибір добра людиною приведе іiі досконалості [9, с. 160-161].

Своєрідним розумінням милосердя у східній (зокрема, індуїстській та буддистській) традиції постає принцип ахімси (ненасильство, неспричинення шкоди живому). Даний принцип був одним iз ключових у житті та діяльності М. Ганді. Найбільш строге тлумачення цього принципу дається в джайнізмі. Головним джерелом ахімси постає, як вказує Д. Датта, любов як внутрішнє почуття в серці. Справжнє ненасильство при цьому не просто відмова від спричинення шкоди чи зла, але виключення $з$ серця людини почуттів ненависті, помсти та гніву. Справжній прояв ахімси грунтується, був переконаний М. Ганді, на внутрішній силі та відсутності страху, адже лише той, хто не боїться інших людей, може їх любити [5, с. 9091]. Кінцевим критерієм ненасильства, вважав М. Ганді, є любов та самовідданість, що виходять 3 глибини душі. В його філософії ахімса постає вищою чеснотою, без неї неможливо осягнути Істину (Бога). Бог же може бути осягнутий лише через любов до нього, а любов до Бога означає любов до живих істот, в яких він втілений [5, с. 92-93].

В цілому для культури Сходу любов постає не як почуття, пристрасть, а, насамперед, як співстраждання, співпереживання за іншу істоту, що виражено у бажанні допомогти. Зокрема, у випадку з буддизмом, як відзначає А. Черепанов, «це бажання допомогти виражається у тому, щоб спрямувати істоту на істинний шлях, який веде до звільнення від страждання» [12, с. 125]. На противагу християнству, любов у буддизмі замінюється почуттям співстраждання, яке базується на тотожності двох страждаючих самостей. Так, «у християнстві мій «ближній» $є$ індивідуальність, особа мені протилежна, єдина і неповторна; в буддизмі множина різних індивідуальностей $є$ ілюзія, магія, насправді всі вони - одне, тотожні в своїй сутності, в серці- нерозрізнювані...». Отже, у буддизмі «немає єдності протилежностей, що 
складає сутність любові..., тут тотожність осіб у байдужому, однаковому стражданні, що має своєю межею повне «угасання» всякої індивідуальної відмінності в «нірвані» [4, с. 276-277].

\section{Висновки.}

Соціокультурний фактор зумовленості уявлень про милосердя постає визначальним в контексті дихотомії «Захід-Схід», що формує різні підходи до сприйняття даного феномену. Західна культура, більш прагматично орієнтована, базується на філософсько-науковому світогляді та християнстві. Милосердя тут розуміється не як моральний імператив, а як вибір людини, прояв їі ставлення до інших. Людина постає індивідом, яка діє завдяки своїй свободі волі, має місце пріоритет людини над суспільним та державою. Об'єктом милосердя постає людина, натомість природа сприймається як об'єкт володіння та використання для потреб людини. Суспільна практика милосердя втілюється в діяльності благодійних, волонтерських та інших гуманітарних організацій та базується на поєднанні індивідуальної та суспільної користі. В свою чергу східна парадигма мислення базується на релігійних нормах, моралі, є більш духовно зорієнтованою, сприймає феномен милосердя як невід'ємний атрибут людського буття, а саму людину як частинку цілого (природи, космосу тощо), найперше як члена спільноти. Звідси об'єктом милосердя постає не лише людина, а все живе, гармонія якого не може бути порушена. Милосердя потребує в певній мірі кооперації, але не інституціоналізації.

\section{БІБІЛІОГРАФІЧНІ ПОСИЛАННЯ}

1. Берестовская Д. С. Диалог культур: Восток и Запад / Д. С. Берестовская // Мыслители ХХ века о культуре: монография. - Симферополь: ИТ «Ариал», 2010. - С. 126-139.

2. Борзова Е. П. Восток и Запад: сравнительный анализ культур / Е. П. Борзова // Труды Санкт-Петербургского государственного института культуры. - 2010. - Т. 190. - С. 282-311.

3. Васильев В. В. Проблематика ценностных ориентаций в компаративистике России, Запада и Востока: автореф. дисс. канд. филос. наук: спец. 09.00.11. / В. В. Васильев. - СПб., 2006. - 21 с.

4. Вышеславцев Б. П. Вечное в русской философии // Этика преображенного Эроса / Б. П. Вышеславцев. - М.: Республика, 1994. - С. 153-350.

5. Датта Д. Философия Махатмы Ганди / Д. Датта; пер. с англ. А.В. Радугина. - М.: Изд-во иностранной литры, 1959. - 146 с.

6. Поломошнов П. А. Исламская и христианская антропология как альтернативные версии религиозного гуманизма / П. А. Поломошнов, А. Ф. Поломошнов // Исламоведение. - 2017. - № 1. - С. 5 -18.

7. Поломошнов П. А. Проблема личности в исламе / П. А. Поломошнов // Исламоведение. - 2015. - № 4. - С. 78-88.

8. Самохвалова В. И. Восток и Запад: о различии идеологических векторов в культуре / В. И. Самохвалова // Ориентиры. - 2010. - № 6. - С. 121-145.

9. Смирнов А. В. «Благо» и «зло» в исламской традиции и философии (к постановке вопроса). Избранные тексты / А. В. Смирнов // Этическая мысль. - 2007. - № 8. - С. 154-193.

10. Степин В. С. Глобализация и диалог культур: проблема ценностей / В. С. Степин // Век глобализации. 2011. - № 2. - C. 8-17.

11. Тихонова Е. П. «Восток-Запад» - знаковая веха культурной рефлексии XX-XXI вв. / Е. П. Тихонова // Вестник Томского государственного университета. - 2007. - № 298. - С. 83-86.

12. Черепанов А. Любовь в категориях буддийской культуры / А. Черепанов // Вестник Челябинского государственного университета. Философия. - 2005. - Т. 10. - № 1. - С. 121-129.

13. Швачкина Л. А. Гуманность в контексте культурных традиций Востока и Запада: автореф. дисс. д-ра филос. наук: спец. 24.00.01. / Л. А. Швачкина. - Ростов-на-Дону, 2011. - 46 с.

14. Шелковая Н. В. Восток и Запад: культура сердца и культура разума / Н. В. Шелковая // Соловъевские исследования. - 2017. - № 2. - С. 143-151.

\section{REFERENCES}

1. Berestovskaia, D.S. (2010). Dialog kultur: Vostok i Zapad [Dialogue of Cultures: East and West]. In Thinkers of the twentieth century about culture: monograph. Simferopol: Arial, (pp. 126-139) [in Russian].

2. Borzova, E.P. (2010). Vostok i Zapad: sravnitelnyi analiz kultur [East and West: a comparative analysis of cultures]. Proceedings of the St. Petersburg State Institute of Culture, 190, 282-311 [in Russian].

3. Vasilev, V.V. (2006). Problematika tcennostnykh orientatcii v komparativistike Rossii, Zapada i Vostoka [The problematics of value orientations in the comparativistics of Russia, the West and the East]. Extended abstract of candidate's thesis. Sankt-Peterburg [in Russian]. 
4. Vysheslavtcev, B.P. (1994). Vechnoe v russkoi filosofii [Eternal in Russian philosophy]. Ethics of the transformed Eros. Moscow: Respublika, (pp. 153-350) [in Russian].

5. Datta, D. (1959). The Philosophy of Mahatma Gandhi. Moscow: Izdatelstvovo inostrannoi literatury [in Russian]. 6. Polomoshnov, P.A., \& Polomoshnov, A.F. (2017). Islamskaia i khristianskaia antropologiia kak alternativnye versii religioznogo gumanizma [Islamic and Christian anthropology as alternative versions of religious humanism]. Islamic Studies, 1, 5-18 [in Russian].

7. Polomoshnov, P.A. (2015). Problema lichnosti v islame [The problem of personality in Islam]. Islamic Studies, 4, 78-88 [in Russian].

8. Samokhvalova, V.I. (2010). Vostok i Zapad: o razlichii ideologicheskikh vektorov v culture [East and West: on the difference of ideological vectors in culture]. Landmarks, 6, 121-145 [in Russian].

9. Smirnov, A.V. (2007). «Blago» i «zlo» v islamskoi traditcii i filosofii (k postanovke voprosa). Izbrannye teksty [«Good» and «evil» in the Islamic tradition and philosophy (to the formulation of the question). Selected texts]. Ethical thought, 8, 154-193 [in Russian].

10. Stepin, V.S. (2011). Globalizatciia i dialog kultur: problema tcennostei [Globalization and the dialogue of cultures: the problem of values]. The age of globalization, 2, 8-17 [in Russian].

11. Tikhonova, E.P. (2007). «Vostok-Zapad» - znakovaia vekha kulturnoi refleksii XX-XXI vv. [«East-West» a landmark of cultural reflection of the XX-XXI centuries]. Bulletin of Tomsk State University, 298, 83-86 [in Russian].

12. Cherepanov, A. (2005). Liubov v kategoriiakh buddiiskoi kultury [Love in the categories of Buddhist culture]. Bulletin of Chelyabinsk State University. Philosophy, 10 (1), 121-129 [in Russian].

13. Shvachkina, L.A. (2011). Gumannost v kontekste kulturnykh traditcii Vostoka i Zapada [Humanity in the context of the cultural traditions of the East and West]. Extended abstract of Doctor's thesis. Rostov-na-Donu [in Russian]. 14. Shelkovaia, N.V. (2017). Vostok i Zapad: kultura serdtca i kultura razuma [East and West: culture of the heart and culture of mind]. Solovyov's researches, 2, 143-151 [in Russian].

\title{
Ходанич Юрій Михайлови
}

Викладач

Ужгородський національний університет

88000, м. Ужгород, пл. Народна, 3

\author{
Khodanych Yuriy \\ Lecturer \\ Uzhgorod National University \\ 3, Narodna sq., 88000, Uzhgorod, Ukraine
}

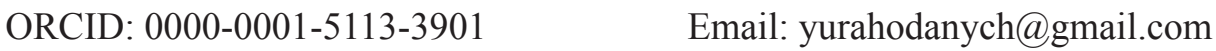

Цитування: Ходанич Ю. М. Феномен милосердя в дихотомії «Захід-Схід» / Ю. М. Ходанич // Науково-теоретичний альманах «Грані». - 2018. - Т. 21. - № 3. - С. 132-138.

Citation: Khodanych, Yu.M. (2018). Fenomen myloserdia v dykhotomii «Zakhid-Skhid» [Phenomenon of Mercy in the Dichotomy «West-East»]. Scientific and theoretical almanac «Grani», 21(3), 132-138. 